\title{
UPAYA PENGENTASAN MASALAH HUBUNGAN \\ SOSIAL (HSO) PESERTA DIDIK \\ MELALUI PELAYANAN BK
}

\author{
Al Halik \\ Institut Agama Islam Negeri (IAIN) Metro Lampung \\ alhalik6@gmail.com
}

\begin{abstract}
This research is based by the results of the Alat Ungkap Masalah (AUM) Umum given to students. The results of the AUM Umum revealed that the Social Relations (HSO) problem is still high compared to the other problem areas. The problems of HSO experienced, such as: 1) the students are not fluent in communicating with their friends, 2) feel not considered important, underestimated, or condemned by others 3) slow in establishing friendships 4) irritability, 5) feel the attention, talk about, or plugged in others etc. The research method used is Action Research (PT) by using guidance and counseling services as an effort to overcome students HSO problems. The research procedure is in the form of a cycle. Each cycle consists of four stages including: planning, actions execution, observation and reflection. Technique of data welding through observation, interviews and inventories (General AUM) format 2. The results showed that there was a decrease in the percentage of problems from cycle I to Cycle II, in cycle 1 HSO problems amounted to $27.08 \%$, while in cycle 2 the there is a percentage decrease to $10 \%$. It can be concluded that guidance and counseling services can overcome the students' HSO problems.
\end{abstract}

Keywords: AUM Umum ; Guidance and counseling services; Social relations problems (HSO) 


\section{A. Pendahuluan}

Manusia merupakan makhluk sosial yang senantiasa membutuhkan orang lain untuk melakukan interaksi serta membentuk hubungan di lingkungannya. Hubungan sosial ini terus berlangsung dan berkembang hingga individu tersebut dewasa. ${ }^{1}$ Meskipun manusia memiliki tangung jawab sebagai makhluk individual, tetapi manusia dalam memenuhi kebutuhannya juga membutuhkan orang lain. Pemenuhan kebutuhan dilakukan dengan cara bersosialisasi dan berinteraksi dengan manusia lainnya. Manusia yang mampu hidup dan bersosialisasi baik dilingkungan maka di diri manusia tersebut terjalin keseimbangan dalam perkembangannya, artinya keindividualan individu berkembang seimbang dengan berkembangnya kesosialan diri individu. Manusia yang berkualitas adalah manusia yang dapat mengembangkan dimensi-dimensi kemanusiaannya meliputi dimensi kefitrahan, keindividualan, kesosialan, kesusilaan dan keberagamaan. ${ }^{2}$

Hubungan sosial dimulai sejak lahir, misalnya dengan Ibu yang melahirkan atau dengan keluarganya. Selanjutnya terus pada masa anak-anak, remaja akan berinterkasi dan bersosialisasi dengan teman-temannya di sekolah dan guru, hingga dewasa interaksi terus bertambah luas. Proses sosialisasi akan berjalan bersamaan dengan proses pencarian identitas pribadi. Sosialisai akan menguatkan kesadaran atas identitas pribadi, sedangkan perkembangan identitas pribadi akan membantu remaja berhadapan dengan harapan masyarakat. ${ }^{3}$

Pada masa remaja kebutuhan menempatkkan diri di masyarakat merupakan sebuah tantangan baginya, karena pada masa ini bersamaan dengan masa pencariaan identitas pribadi. Sehingga tak jarang terjadi permasalahan bagi remaja dalam memenuhi harapan dari masyarakat, orangtua, keluarga hingga teman sebaya. Hal ini akan menjadi tantangan bagi remaja untuk membuat perubahan dalam hubungan sosial mereka. Geldard menjelaskan bahwa masyarakat, keluarga, serta sekolah sering gagal dalam mengarahkan tujuan yang sejalan, sehingga remaja

${ }^{1}$ Fatimah, Psikologi Perkembangan, (Bandung: CV. Pustaka Setia, 2006)

2 Prayitno, Dasar Teori dan Praksis Pendidikan, (Padang: Grasindo, 2009)

3 Geldard, Kathryn dan David Geldard, Konseling Remaja: Pendekatan Proaktif untuk Anak Muda, (Yogyakarta: Pustaka Pelajar, 2010) 
menunjukkan perilaku hubungan sosial yang tidak diharapkan serta mengalami kebingungan. ${ }^{4}$

Permasalahan tersebut sering terjadi di lingkungan sekolah, di mana peserta didik yang berada pada masa usia remaja sering menghadapi masalah ketika berhubungan sosial dengan teman sebayanya. Sekolah sebagai satu lembaga pendidikan dapat mempengaruhi perkembangan sosial remaja secara optimal, karena tujuan pendidikan salah satunya ialah membantu peserta didik mengembangkan hubungan sosialnya. Sekolah menjadi tempat terjadinya proses belajar dan interaksi sosial sehingga peserta didik dapat belajar berinteraksi dan bergaul dengan sesamanya. Putri dan Budi menyatakan Sekolah juga menjadi wahana proses sosialisasi pengenalan nilai antar peserta didik, antar pendidik, antara pendidik dan peserta didik dan sebaliknya. ${ }^{5}$ Kemampuan peserta didik dalam membina hubungan sosial dengan lingkungannya menandakan bahwa ia telah mencapai salah satu dari tugas-tugas perkembangannya. Tercapainya tugas perkembangan memberikan arti bahwa potensi peserta didik sudah berkembangan secara optimal. Namun, kenyataannya di lapangan masih banyaknya peserta didik kesulitan dalam menjalin hubungan sosial dengan temanya.

Berdasarkan hasil rata-rata skor masalah HSO (Hubungan Sosial) saat pengadministrasian AUM Umum pada seluruh kelas XI IPS 2 SMA Negeri 1 Lubuk Alung terdapat 27,8\% masalah. Selain itu, berdasarkan hasil wawancara kepada beberapa orang peserta didik didapatkan keterangan bahwa terjadinya kesenjangan hubungan sosial antara laki-laki dan perempuan, dalam bermain dan belajar terdapat kelompok-kelompok yang memisahkan diri dari teman sekelas, kurangnya kekompakkan, kurangnya rasa saling menghargai sehingga terjadi hubungan yang tidak harmonis. Diperkuat dengan hasil sosiometri yang penulis administrasikan, terungkaplah fakta bahwa masih banyaknya kelompok-kelompok terisolir di kelas tersebut. Kemudian, hasil wawancara kepada guru bimbingan dan konseling diperoleh keterangan memang ada masalah sosial

4 Ibid.

5 Putri, Budi, Hubungan antara Dukungan Sosial Ayah dengan Penyesuaian Sosial pada Remaja Laki-laki. Jurnal Psikologi, 2003, (1). h, 23-35 
yang terjadi, seperti dibentuknya kelompok-kelompok ekslusif yang merasa lebih baik dan hebat yang kadang akhirnya cenderung memicu konflik, antar kelompok enggan saling tolong menolong kalau temanya berada di luar kelompoknya.

Masalah hubungan sosial yang dialami peserta didik harus dibantu dan dicari upaya penyelesaiannya, karena hubungan sosial dengan temannya di lingkungan berguna untuk mengembangkan kemandirian. Yusuf menjelaskan bahwa sikap kemandirian dan kemantangan hubungan antarpribadi remaja yang berkembang secara matang dapat dipelajari dan diperoleh dari proses pengalaman berinteraksi remaja dalam kelompok teman sebayanya. ${ }^{6}$ Maka dari itu, peserta didik perlu dibantu untuk menguasai tugas perkembangan sosial secara optimal. Salah satu upaya yang bisa dilakukan pendidik yaitu dengan cara menjalin interaksi serta membina hubungan dalam proses pembelajaran, sehingga tercapainya tujuan pembelajaran. Salah satu personil sekolah yang membantu peserta didik dalam upaya pengentasan masalah hubungan sosialnya adalah guru pembimbing atau guru BK. Keprofesionalan guru BK sangat dibutuhkan dalam membantu pengentasan masalah peserta didik dalam bidang apapun, sehingga kehidupan peserta didik sehari-hari lebih efektif.

Prayitno mengungkapkan bahwa pembelajaran BK diselenggarakan melalui pemberian sepuluh jenis layanan BK, untuk membantu pengembangan pribadi, kemampuan sosial, kemampuan belajar dan perkembangan karir peserta didik, serta mampu mampu mengoptimalkan pencapaian tugas perkembangan peserta didik. ${ }^{7}$ Guru BK membantu peserta didik mengaktualisasikan dirinya secara optimal, sehingga dapat terwujudnya peserta didik yang berhasil sebagai pribadi yang mandiri, dapat berinteraksi, bersosialisasi, dan sehingga peserta didik dalam kehidupannya sehari-hari bisa dijalani secara efektif. Khalilah menjelaskan bahwa Layanan BK bidang bimbingan pribadi dan sosial menjadi salah satu upaya mengembangkan keterampilan hubungan sosial siswa. Layanan tersebut

6 Yusuf, Psikologi Perkembangan Anak dan Remaja, (Bandung: PT Remaja Rosdakarya, 2011)

7 Prayitno, Konseling Integritas: Pola Konseling Indonesia. (Padang: Universitas Negeri Padang, 2014) 
membantu siswa yang mengalami masalah pribadi dan sosial dapat secara mandiri memecahkan masalahnya. Sehingga siswa mampu menyesuaikan diri secara pribadi sosial, memilih kelompok dan kegiatan sosial yang bermanfaat untuk dirinya. ${ }^{8}$

\section{B. Metode Penelitian}

Penelitian tindakan merupakan jenis penelitian yang digunakan dalam penelitian ini. Penelitian tindakan (Action Research) adalah penelitian yang melakukan tindakan nyata dengan menggunakan langkah penelitian yang digabungkan dengan rangkaian tindakan dalam mencari dan memecahkan masalah. ${ }^{9}$ Penelitian ini menggunakan tindakan diterapkan dalam layanan BK sehingga disebut sebagai penelitian tindakan layanan (PTL), yang terdiri dari empat tahap yaitu: 1) perencanaan, 2) pelaksanaan, 3) pengamatan, dan 4) refleksi.

Penelitian ini dilakukan secara kolaborasi antara peneliti, guru BK dan siswa kelas XI IPS 2 SMAN 1 Lubuk Alung yang berjumlah 32 orang. Penelitian ini diberikan tindakan dengan dua siklus, di mana setiap siklus ada empat tahap; perencanaan, pelaksanaan, pengamatan, dan refleksi. ${ }^{10}$ Hasil dikumpulkan dengan menggunakan Alat Ungkap Masalah Umum (AUM UMUM) Format 2, observasi dan wawancara langsung atau penilaian langsung dengan cara menanyakan tanggapan siswa terhadap kegiatan layanan BK yang diterima. Pengadaan penilaian dilaksanakan pada setiap akhir siklus. Data yang di peroleh dianalisis sesuai dengan langkah perhitungan AUM yang telah baku. Penelitian ini diukur apabila rata-rata persentase masalah yang dihadapi turun dari sebelumnya, serta berkembangnya hubungan sosial siswa di lingkungan sekolah terutama di kelas.

8 Khalilah, Layanan Bimbingan dan Konseling Pribadi Sosial dalam Meningkatkan Keterampilan Hubungan Sosial Siswa. Journal of Islamic Guidance and Counseling, 2017, 1(1). h. 41-57

9 Hidayat, Rahmat, Badrujaman, Penelitian Tindakan dalam Bimbingan Konseling. (Jakarta, PT Indeks, 2012)

10 Arikunto, Penilaian dan Penelitian Bidang Bimbingan dan Konseling. (Yogyakarta: Aditya Media, 2011) 


\section{Hasil dan Pembahasan}

Upaya pengentasan masalah hubungan sosial peserta didik dengan mengunakan layanan BK (layanan konseling dan bimbingan kelompok serta penguasaan konten), bahwa terjadi penurunan masalah hubungan sosial yang dihadapi oleh peserta didik. Penurunan terjadi berdasarkan indikator yang telah digunakan dengan cara memberikan inventori berupa Alat Ungkap Masalah Umum (AUM- Umum). Data yang diperoleh disajikan dalam tabel-tabel berikut.

\section{Tabel 1. Masalah Hubungan Sosial Peserta Didik Siklus I}

\begin{tabular}{|c|c|c|c|c|c|c|c|c|c|}
\hline \multirow[b]{2}{*}{ No } & \multirow[b]{2}{*}{$\begin{array}{l}\text { BIDANG } \\
\text { MASALAH }\end{array}$} & \multirow[b]{2}{*}{$\begin{array}{l}\text { Jml } \\
\text { Item }\end{array}$} & \multicolumn{5}{|c|}{ MASALAH KESELURUHAN } & \multicolumn{2}{|c|}{ MASALAH BERAT } \\
\hline & & & $\begin{array}{l}\text { Ter- } \\
\text { rendah }\end{array}$ & \begin{tabular}{|c} 
Ter- \\
tinggi
\end{tabular} & $\begin{array}{c}\text { Jml } \\
\text { Masalah }\end{array}$ & $\%$ & $\begin{array}{l}\text { Rata-rata } \\
\text { persiswa }\end{array}$ & $\mathrm{Jml}$ & $\begin{array}{l}\text { Rata-rata } \\
\text { persiswa }\end{array}$ \\
\hline 1 & 2 & 3 & 4 & 5 & 6 & 7 & 8 & 9 & 10 \\
\hline 1 & $\mathrm{HSO}$ & 15 & 0 & 13 & 117 & 27,8 & 3,65 & 16 & 0.50 \\
\hline
\end{tabular}

Diadopsi dari pedoman hasil pengolahan AUM seri Umum format 2.

Tabel 1 di atas mengambar kondisi masalah hubungan sosial pesesta didik yang didapatkan dari 32 orang siswa. Pada bidang HSO ini terdiri atas 15 item pertanyaan, dengan masalah keseluruhan tertinggi 13 item dan terendah 0 item. Artinya, jumlah masalah keseluruhan yang dialami siswa yaitu sebanyak 117 item dengan persentase sebesar 27,8\%.

Tabel 2. Masalah Hubungan Sosial Peserta Didik Siklus II

\begin{tabular}{|c|c|c|c|c|c|c|c|c|c|}
\hline \multirow{2}{*}{ No } & BIDANG & Jlm & \multicolumn{4}{|c|}{ MASALAH KESELURUHAN } & MASALAH BERAT \\
\cline { 4 - 10 } & MASALAH & item & $\begin{array}{c}\text { Ter- } \\
\text { rendah }\end{array}$ & $\begin{array}{c}\text { Ter- } \\
\text { tinggi }\end{array}$ & $\begin{array}{c}\text { Jml } \\
\text { Masalah }\end{array}$ & $\%$ & $\begin{array}{c}\text { Rata-rata } \\
\text { persiswa }\end{array}$ & Jml & $\begin{array}{c}\text { Rata-rata } \\
\text { persiswa }\end{array}$ \\
\hline 1 & 2 & 3 & 4 & 5 & 6 & 7 & 8 & 9 & 10 \\
\hline 1 & HSO & 15 & 0 & 5 & 24 & 10 & 1,5 & 2 & 0,12 \\
\hline
\end{tabular}

Diadopsi dari pedoman hasil pengolahan AUM seri Umum

Tabel di atas mengambarkan bahwa masalah hubungan sosial pesesta didik yang didapatkan dari 32 orang siswa. Pada bidang HSO ini terdiri atas 15 item pertanyaan, dengan masalah keseluruhan tertinggi 5 item dan terendah 0 item. Jumlah masalah keseluruhan yang dialami siswa yaitu sebanyak 24 item dengan persentase sebesar $10 \%$, artinya terdapat penurun masalah hubungan sosial yang dihadapi oleh siswa setelah mendapatkan layanan BK (layanan konseling dan bimbingan 
kelompok serta penguasaan konten). Hasil siklus I peserta didik yang mengalami masalah hubungan sosial sebesar $27 \%$ dan setelah siklus II menurun menjadi $10 \%$.

Berikut ditampilkan bentuk masalah-masalah hubungan sosial peserta didik peritem yang ada di AUM Umum format 2 sebagai berikut.

\section{Tabel 3. Masalah Hubungan Sosial (HSO) Peserta didik per} item di Siklus I

\begin{tabular}{|c|l|c|c|c|}
\hline No & \multicolumn{1}{|c|}{ Jenis Masalah } & $\begin{array}{c}\text { Jml } \\
\text { Masalah }\end{array}$ & $\%$ & $\begin{array}{c}\text { Rata-rata } \\
\text { Persiswa }\end{array}$ \\
\hline 1 & $\begin{array}{l}\text { Tidak menyukai atau tidak disukai } \\
\text { seseorang }\end{array}$ & 12 & 37,5 & 0,37 \\
\hline 2 & $\begin{array}{l}\text { Merasa diperhatiakan, dibicarakan, } \\
\text { atau diperolokkan orang lain. }\end{array}$ & 13 & 40,62 & 0,40 \\
\hline 3 & $\begin{array}{l}\text { Mengalami masalah karena ingin } \\
\text { lebih terkenal atau lebih menarik, } \\
\text { atau lebih menyenangkan bagi } \\
\text { orang lain. }\end{array}$ & 11 & 34,37 & 0,34 \\
\hline 4 & $\begin{array}{l}\text { Mempunyai kawan yang kurang } \\
\text { disukai orang lain }\end{array}$ & 4 & 12,5 & 0,12 \\
\hline 5 & $\begin{array}{l}\text { Tidak mempunyai kawan akrab, } \\
\text { hubungan sosial terbatas, atau } \\
\text { terisolir. }\end{array}$ & 5 & 15,62 & 0,15 \\
\hline 6 & Kurang peduli terhadap orang lain & 4 & 12,5 & 0,12 \\
\hline 7 & Rapuh dalam berteman & 7 & 21,87 & 0,21 \\
\hline 8 & $\begin{array}{l}\text { Merasa tidak dianggap penting, } \\
\text { diremehkan, atau dikecam oleh } \\
\text { orang lain. }\end{array}$ & 17 & 53,12 & 0,53 \\
\hline 9 & $\begin{array}{l}\text { Mengalami masalah dengan orang } \\
\text { lain karena kurang peduli terhadap } \\
\text { diri sendiri }\end{array}$ & 4 & 12,5 & 0,12 \\
\hline 10 & $\begin{array}{l}\text { Canggung dan/atau tidak lancar } \\
\text { berkomunikasi dengan orang lain. }\end{array}$ & 8 & 25 & 0,25 \\
\hline 11 & $\begin{array}{l}\text { Tidak lincah dan kurang } \\
\text { mengetahui tentang tata karma } \\
\text { pergaulan. }\end{array}$ & 7 & 21,87 & 0,21 \\
\hline 12 & $\begin{array}{l}\text { Kurang pandai memimpin } \\
\text { dan/atau mudah dipengaruhi } \\
\text { orang lain }\end{array}$ & 6 & 18,75 & 0,18 \\
\hline
\end{tabular}




\begin{tabular}{|c|l|c|c|c|}
\hline 13 & $\begin{array}{l}\text { Sering memantah atau tidak } \\
\text { menyukai suatu yang dikatakan, } \\
\text { dirasakan orang lain, atau } \\
\text { dikatakan sombong }\end{array}$ & 6 & 18,75 & 0,18 \\
\hline 14 & $\begin{array}{l}\text { Mudah tersinggung atau sakit hati } \\
\text { dalam berhubungan dengan orang } \\
\text { lain }\end{array}$ & 9 & 28,12 & 0,28 \\
\hline 15 & Lambat menjalin persahabatan & 6 & 18,75 & 0,18 \\
\hline
\end{tabular}

Dari paparan hasil Alat Ungkap Masalah (AUM) Umum di atas permasalahan yang lebih banyak dialami oleh siswa SMA Negeri 1 RSBI Lubuk Alung yaitu Merasa tidak dianggap penting, diremehkan, atau dikecam oleh orang lain. Pada masalah ini terdapat 17 siswa atau $(53,12 \%)$ dengan rata-rata persiswa 0,53. Analisis masalah per item tersebut menjadi pertimbangan dalam merencanakan materi yang akan diberikan dalam pelaksanaan layanan BK. Dengan demikian diharapkan materi tersebut bisa sesuai dengan masalah yang banyak dihadapi oleh peserta didik.

Menginggat masih tingginya masalah hubungan sosial peserta didik tersebut, maka menjadi pertimbangan untuk melanjutkan siklus II. Setelah pemberian tindakan dan pengumpulan data maka hasilnya sebagai berikut:

\section{Tabel 4. Masalah Hubungan Sosial (HSO) Peserta didik per item pada Siklus I}

\begin{tabular}{|c|l|c|c|c|}
\hline No & \multicolumn{1}{|c|}{ Jenis Masalah } & $\begin{array}{c}\text { Jml } \\
\text { Masalah }\end{array}$ & \% & Rata-rata \\
\hline 1 & $\begin{array}{l}\text { Tidak menyukai atau tidak disukai } \\
\text { seseorang }\end{array}$ & 3 & 18,75 & 0,18 \\
\hline 2 & $\begin{array}{l}\text { Merasa diperhatiakan, dibicarakan, } \\
\text { atau diperolokkan orang lain. }\end{array}$ & 4 & 25 & 0,25 \\
\hline 3 & $\begin{array}{l}\text { Mengalami masalah karena ingin } \\
\text { lebih terkenal atau lebih menarik, } \\
\text { atau lebih menyenangkan bagi } \\
\text { orang lain. }\end{array}$ & 1 & 6,25 & 0,06 \\
\hline 4 & $\begin{array}{l}\text { Mempunyai kawan yang kurang } \\
\text { disukai orang lain }\end{array}$ & 0 & 0 & 0 \\
\hline 5 & $\begin{array}{l}\text { Tidak mempunyai kawan akrab, } \\
\text { hubungan sosial terbatas, atau } \\
\text { terisolir. }\end{array}$ & 0 & 0 & 0 \\
\hline 6 & Kurang peduli terhadap orang lain & 0 & 0 & 0 \\
\hline 7 & Rapuh dalam berteman & 0 & 0 & 0 \\
\hline
\end{tabular}




\begin{tabular}{|c|l|c|c|c|}
\hline 8 & $\begin{array}{l}\text { Merasa tidak dianggap penting, } \\
\text { diremehkan, atau dikecam oleh } \\
\text { orang lain. }\end{array}$ & 3 & 18,75 & 0,18 \\
\hline 9 & $\begin{array}{l}\text { Mengalami masalah dengan orang } \\
\text { lain karena kurang peduli terhadap } \\
\text { diri sendiri }\end{array}$ & 2 & 12,5 & 0,12 \\
\hline 10 & $\begin{array}{l}\text { Canggung dan/atau tidak lancar } \\
\text { berkomunikasi dengan orang lain. }\end{array}$ & 2 & 12,5 & 0,12 \\
\hline 11 & $\begin{array}{l}\text { Tidak lincah dan kurang } \\
\text { mengetahui tentang tata karma } \\
\text { pergaulan. }\end{array}$ & 0 & 0 & 0,06 \\
\hline 12 & $\begin{array}{l}\text { Kurang pandai memimpin } \\
\text { dan/atau mudah dipengaruhi } \\
\text { orang lain }\end{array}$ & 2 & 12,5 & 0,12 \\
\hline 13 & $\begin{array}{l}\text { Sering memantah atau tidak } \\
\text { menyukai suatu yang dikatakan, } \\
\text { dirasakan orang lain, atau } \\
\text { dikatakan sombong }\end{array}$ & 3 & 18,75 & 0,18 \\
\hline 14 & $\begin{array}{l}\text { Mudah tersinggung atau sakit hati } \\
\text { dalam berhubungan dengan orang } \\
\text { lain }\end{array}$ & 0 & 0 & 0 \\
\hline 15 & \begin{tabular}{l} 
Lambat menjalin persahabatan \\
\hline
\end{tabular}
\end{tabular}

Tabel 3 dan 4 di atas mengambarkan bahwa terdapat penurunan setiap item masalah, artinya pemberian layanan BK pada siklus I dan siklus II dapat membantu pengentasan masalah hubungan sosial yang dihadapi oleh peserta didik. Setelah dievaluasi ternyata belum sepenuhnya terentaskan masalah hubungan sosial peserta didik tersebut, karena masih adanya beberapa item yang masih menjadi masalah bagi beberapa peserta didik.

Hubungan sosial di mulai dari tingkat sederhana yang terus berkembang hingga dewasa. Semakin dewasa maka kebutuhan saling membutuhkan akan menjadi semakin kompleks. Peserta didik yang pada masa perkembangannya mengalami kesulitan dan hambatan dalam berinteraksi dengan lingkungan misalnya orangtua, keluarga, sekolah dan teman sebaya dapat mempengaruhi perkembangan sosialnya. Tugas perkembangan sosial yang kurang berkembang pada masa remaja dapat berpengaruh pada kehidupan sosialisasinya pada masa dewasa, karena tingkah laku yang dibawa cenderung berubah dari yang dibawa. 
Masa remaja menjadi masa di mana individu mulai banyak berhubungan sosial dengan lingkungan, sehingga pada masa ini tingkah laku sosial remaja berkembang lebih matang serta memperoleh nilai-nilai yang berbeda. Perkembangan tingkah laku sosial yang matang remaja dipengaruhi oleh tiga faktor yaitu orangtua, sekolah dan teman sebaya. ${ }^{11}$ Keluarga atau lingkungan rumah menjadi faktor pertama yang memberi pengaruh perkembangan hubungan sosial individu. Hubungan sosial individu akan terus berkembang seiring dengan perkembangannya yaitu ke lingkungan sekolah. Hubungan sosial ini terus berlanjut ke lingkungan yang lebih luas yaitu lingkungan teman sebaya. Remaja dinilai oleh teman sebayanya tanpa memperdulikan sanksi orang dewasa. Sehingga nilai yang berlaku bukanlah nilai yang ditetapkan oleh orang dewasa melainkan oleh teman seusianya. ${ }^{12}$

Keberhasilan orangtua ketika mendidik anaknya, memberi pengaruh pada perkembangan berikutnya. Bisa saja ini menjadi penyebab individu memiliki masalah dalam berhubungan sosial di lingkungan yang lebih luas. Berdasarkan hasil penelitian Maria menyatakan bahwa keharmonisan keluarga memberikan peran terhadap kecenderungan terhadap kenakalan remaja sebesar 7,2\% serta konsep diri memberikan peran kecenderungan terhadap kenakalan remaja sebesar 30,5\%. ${ }^{13}$ Perkembangan sosial seorang anak bisa tampak dari terpenuhinya kebutuhan seperti rasa aman, dihargai, disayangi, diterima, dan teraktualisasikan dirinya. Jika di dalam lingkungan keluarga tumbuh dan berkembang sikap penerimaan dan tertampilnya tingkah laku positif, maka tumbuh dan berkembang juga konsep diri positif dalam diri anak.

Konsep diri memegang peranan penting bagi pembentukkan tingkah laku individu ketika akan bersosialisasi di lingkungan yang lebih luas. Konsep diri terbentuk dari hasil belajar dan pengalaman anak dalam berinteraksi dengan lingkungan terdekat dan realitas dunia. Budi Andayani dan Tina

11 Mudjiran, Perkembangan Peserta Didik. (Padang: Dirjen Pendidikan Tinggi, 2001)

12 Sarwono, Psikologi Remaja, (Depok: PT. Rajagrafindo Persada, 2011).

13 Maria, Ulfah and, Prof.Dr. Sartini Nuryoto (2007) Peran persepsi keharmonisan keluarga dan konsep diri terhadap kecenderungan kenakalan remaja. UNSPECIFIED thesis, UNSPECIFIED. 
Afiatin menyatakan bahwa konsep diri memiliki hubungan yang sangat besar terhadap harga diri dan kepercayaan diri remaja. ${ }^{14}$ Lebih lanjut Burns menjelaskan konsep diri yang terbentuk membuat individu dapat mengantisipasi reaksi dalam melakukan interaksi sosial dengan orang lain. ${ }^{15}$ Artinya reaksi anak bertingkah laku terhadap lingkungan sebagaimana konsep diri yang tumbuh dan berkembang didirinya.

Faktor sukses tidaknya hubungan sosial individu dalam lingkungan sosialnya yaitu konsep diri yang dimiliki oleh remaja. Semakin tinggi konsep diri remaja maka akan memiliki hubungan sosial yang baik pula dibandingkan remaja yang memiliki konsep diri yang rendah. ${ }^{16}$ Selanjutnya Gita, Zulpahiyana, dan Siti mengungkapkan berdasarkan hasil penelitiannya bahwa faktor yang memberikan pengaruh secara signifikan terhadap konsep diri remaja yaitu pola asuh, orangtua, teman sebaya dan peranan harga diri. ${ }^{17}$ Artinya bahwa remaja yang memiliki pola asuh permisif dan teman sebaya yang buruk serta harga diri yang rendah cenderung memiliki konsep diri yang negatif.

Pada kenyataannya di lingkungan sekolah masih banyak peserta didik mengamalami masalah hubungan sosial. Berdasarkan temuan penelitian item AUM-Umum dari masalah hubungan sosial yang banyak dialami oleh peserta didik yaitu merasa tidak dianggap penting, diremehkan, atau dikecam oleh orang lain, perasaan ingin lebih terkenal atau lebih menarik, atau lebih menyenangkan, merasa diperhatikan, dibicarakan, atau diperolokkan orang lain dan tidak menyukai atau tidak disukai seseorang. Hal ini diduga karena peserta didik masih memiliki konsep diri rendah, sehingga mempengaruhinya dalam menjalin hubungan sosial. Kesulitan ini menimbulkan masalah bagi peserta didik dalam berinteraksi dengan teman sebayanya di

14 Budi Andayani dan Tina Afianti, Konsep Diri, Harga Diri dan Kepercayaan Diri Remaja, Jurnal Psikologi Fakultas Psikologi Universitas Gajah Mada, Vol 23 Nomor 22016.

15 Burs, Konsep Diri : teori, pengukuran, perkembangan, dan perilaku. (Jakarta: Arcan, 1993) 2006)

16 Elida Prayitno, Psikologi Perkembangan Remaja. (FIP. UNP Padang,

${ }_{17}$ Gita, Zulpahiyana, dan Siti, Faktor-faktor yang Mempengaruhi Konsep Diri Remaja, Jurnal Ners dan Kebidanan Indonesia, 3 (1) 2015, h.33-38 
lingkungan sekolah, tidak dapat membangun komitmen bersama dalam kelompok atau organisasinya, tidak mampu bekerjasama, kurang rasa saling menghargai, enggan saling membantu serta kurangnya rasa saling menghormati.

Interaksi yang tidak baik dan terbuka di lingkungan menjadikan individu memiliki nilai yang tidak berkembang pula. Perkembangan sosial antara individu tidak selalu berjalan lancar karena perbedaan dari masing-masing individu baik dalam segi pemikiran dan kepribadian. Perbedaan tersebut dapat menjadi salah satu faktor pemutusan hubungan sosial. Sikap yang tidak mau menerima, menyalahkan dan merendahkan orang lain dapat merusak hubungan sosial di antara individu. Individu akan menarik diri dari lingkungan sosial apabila ia belum siap menghadapi resiko dan menerima perbedaan sikap terkait dengan apa yang disukai orang lain. Ketidaksiapan individu dalam menerima perbedaan sikap memberikan arti bahwa ia tidak menyukai lingkungannya dan meninggalkan lingkungan tersebut. Pada akhirnya individu menciptakan dunianya sendiri sebagai pengalihan dari perasaan sepi, sendiri dan terasing. Padahal seharusnya individu dituntut untuk siap menerima dan menghadapi resiko ketika membangun hubungan sosial dengan orang lain. Menjalin hubungan sosial artinya individu saling memenuhi keinginan dan harapan diri, individu mampu saling membantu dengan orang lain dalm memenuhi keinginan dan harapannya, walau dalam upaya saling membantu terkadang kurang sesuai dengan karakter dan pribadi yang dimiliki orang lain tersebut. ${ }^{18}$

Prayitno mengungkapkan interaksi dengan teman sebaya memberikan kesempatan pada peserta didik remaja belajar keterampilan sosial, mengembangkan minat yang sama, dan saling membantu dalam mengatasi kesulitan untuk mencapai kemandirian. Remaja lebih menyukai berhubungan sosial dengan individu yang mempunyai kesamaan minat dan nilai dengan dirinya. ${ }^{19}$ Bahkan remaja lebih percaya dan mau menceritakan masalah-masalahnya yang tidak bisa diceritakan kepada orang tua dan guru kepada temannya yang mampu mengerti dan

18 Soemanto, 2014, Pengertian dan Ruang Lingkup Sosiologi Keluarga, 145. (Online)

19 Elida Prayitno Op., Cit. 
membuatnya merasa aman. ${ }^{20}$ Artinya bahwa interaksi antar peserta didik memberikan kesempatan kepada mereka untuk belajar dan saling membantu dalam mengatasi masalah. Maka dengan ini peneliti menjadikan pelayanan BK dengan format kelompok sebagai upaya membantu mengentaskan masalah hubungan sosial yang dialami peserta didik sekolah.

Penelitian Ardi, Ibrahim dan Said menjelaskan bahwa upaya yang dapat dilakukan untuk mengoptimalkan tugas perkembangan sosial siswa dengan kelompok teman sebaya adalah dengan melaksanakan bimbingan sosial yang menerapkan berbagai jenis layanan bimbingan dan konseling. Misalnya, bimbingan sosial mengenai cara meningkatkan pemahama dalam menyesuaian diri yang baik dengan teman sebaya, pengembangan kemampuan menyampaikan pendapat, dan meningkatkan kemampuan dan etika bersosialisasi yang baik dengan lawan jenis. Layanan yang dapat diberikan untuk bimbingan sosial ini yaitu: a) penguasaan konten, b) bimbingan kelompok, c) konseling kelompok, dan d) konseling perorangan. ${ }^{21}$

Jenis layanan BK yang diberikan adalah layanan konseling dan bimbingan kelompok. Proses pelaksanaan layanan bimbingan dan konseling kelompok mengupayakan antar anggota kelompok terjadi saling interaksi, komunikasi, berani memberikan dan mengemukan pendapat satu sama lain, serta mampu memecahkan masalah secara bersama-sama. Prayitno menjelaskan bahwa salah satu tingkah laku yang muncul pada masa remaja adalah senang hidup di dalam kelompok, bagi remaja kelompok menjadi tempat berbagi cerita dan rasa, saling mendukung dan belajar berhubungan dengan lawan jenis. ${ }^{22}$ Dari hasil penelitian pelayanan BK dapat mengentaskan masalah hubungan sosial peserta didik bisa dikatakan terbukti kebenarannya. Kebenaran ini dibuktikan dengan adanya penurunan masalah setelah tindakan diberikan pada setiap siklus. Pada setiap akhir siklus yang selesai diberikan tindakan

20 Hurlock, Op., Cit.

21 Ardi, Ibrahim, Said, Capaian Tugas Perkembangan Sosial Siswa Dengan Kelompok Teman Sebaya dan Implikasinya Terhadap Program Pelayanan Bimbingan dan Konseling : Jurnal Konselor, 1(1). 1-8, 2012.

22 Elida Prayitno Op., Cit. 
maka penilaian dilakukan dengan cara observasi dan wawancara langsung atau menanyakan tanggapan anggota kelompok dengan tujuan untuk mengetahui pemahaman terhadap masalahnya, keikutserataan aktif dalam anggota kelompok serta kondisi dan suana diri selama proses pemberian pelayanan BK.

Dari hasil penelitian dapat dimaknai bahwa layanan BK (Bimbingan kelompok, konseling kelompok, dan penguasaan konten) dapat mengatasi masalah hubungan sosial peserta didik. Dari hasil pengamatan peneliti juga tampak berkembangnya hubungan sosial siswa setelah mengikut layanan BK (Layanan Konseling dan bimbingan kelompok serta penguasaan konten), seperti a) Peserta didik mampu untuk bekerjasama dalam kegiatan belajar, walau selama ini ada peserta didik yang belum memiliki teman belajar kelompok, karena sebelumnya mereka hanya belajar dengan teman-teman yang berbeda lokalnya, sekarang sudah mulai mau untuk bekerjasama dalam belajar dengan teman-teman satu lokal, b) Siswa menghargai guru saat menerangkan pelajaran, sudah mulai untuk memperhatikan guru, saling mengingatkan dan sudah berkurang aktifitas siswa yang keluar masuk pada saat pelajaran berlangsung, c) Apabila mengalami kesulitan belajar, mereka sudah mulai bekerjasama dan saling membantu.

Kesungguhan dan keseriusan peserta didik dalam mengikuti kegiatan tersebut memberikan manfaat dalam upaya pengentasan masalahnya. Setelah mengikuti kegiatan bimbingan dan konseling kelompok peserta didik menjadi paham bagaimana mengembangkan hubungan sosial sesama teman serta lingkungan tempat meraka bersosialisasi. Seperti disampaikan salah satu peserta didik yang mengikuti kegiatan konseling dan bimbingan kelompok:

"Selama mengikuti kegiatan bimbingan dan konseling kelompok saya sangat merasa senang dan puas. Kegiatan ini sangat banyak memberikan manfaat, bisa saling membantu, membuat saya berani memberikan pendapat, dan tentunya lebih membuat emosional saya dengan teman-teman yang lain lebih dekat. Permainannya pun membuat kami jujur, dan berani terbuka. Saya berharap kegiatan seperti bisa berlanjut". 
Kemudian, tidak jauh berbeda dengan pendapat di atas:

"Saya sangat senang ikut kegiatan ini, awalnya saya sangat gugup menyampaikan pendapat di depan orang banyak, seperti di depan kelas. Tapi, dengan kegiatan ini, saya sudah berani menyampaikannya, ya, walau masih agak gugup dan keringat kadang-kadang. Tapi aku sudah berani karena teman-teman juga berani. Mungkin alasan pertama saya berani karena saya merasa sudah tidak ada beban dengan teman-teman, saya merasa kita semua sudah dekat dan untuk apa malu-malu lagi dengan apa yang kita bisa sampaikan".

Pelayanan BK menjadi salah satu upaya Guru BK atau konselor dalam membantu dan memfasilitasi peserta didik menjadi mandiri membuat keputusan dan memilih pilihan, menyesuaikan diri dan siap menghadapi resiko dalam hubungan dengan situasi tertentu, mampu memecahkan masalahmasalahnya sehingga peserta didik mampu menjalani hariharinya dengan efektif. Kemampuan peserta didik dalam membina hubungan sosial dengan lingkungannya menandakan bahwa ia telah mencapai salah satu dari tugas-tugas perkembangannya. Tercapainya tugas perkembangan memberikan arti bahwa potensi peserta didik sudah berkembangan secara optimal. Dengan demikian peserta didik mampu membentuk suatu konsep diri positif sehingga terbangunlah kemampuan penyesuaian dirinya yang baik tanpa mengalami keterisoliran diri.

\section{Simpulan}

Hasil penelitian tindakan melalui penerapan pelayanan BK (bimbingan kelompok, konseling kelompok) dapat menurunkan masalah hubungan sosial (HSO) peserta didik siswa kelas XI IPS 2 SMAN 1 Lubuk Alung. Kebenaran ini dibuktikan dengan adanya penurunan masalah hubungan sosial setelah tindakan diberikan. Setelah mengikuti kegiatan pelayanan BK peserta didik menjadi paham bagaimana mengembangkan hubungan sosial sesama teman serta lingkungan tempat meraka bersosialisasi.

Setelah penelitian ini, harapan kepada pihak sekolah dapat menyediakan fasilitas yang lebih baik, sehingga peserta didik 
mau memanfaatkan pelayanan BK untuk membantu dirinya ketika mengalami masalah. Guru BK atau konselor terus mengembangkan diri, meningkatkan pelaksanaan pelayanan BK dengan berbagai macam pendekatan dan metode ataupun teknik guna lebih efektifnya pengentasan masalah yang dihadapi peserta didik, Guru BK juga perlu menjalin kerjasama sebagai tindakan preventif, kuratif dan pengembangan dalam membantu peserta didik menyelesaikan permasalahnya.

\section{Daftar Pustaka}

Ardi, Z., Ibrahim, Y., dan Said A. (2012). Capaian Tugas Perkembangan Sosial Siswa Dengan Kelompok Teman Sebaya dan Implikasinya Terhadap Program Pelayanan Bimbingan dan Konseling : Jurnal Konselor, 1(1). 1-8

Arikunto, S. (2011). Penilaian dan Penelitian Bidang Bimbingan dan Konseling. Yogyakarta: Aditya Media

Budi Andayani dan Tina Afianti, (2016) Konsep Diri, Harga Diri dan Kepercayaan Diri Remaja, Jurnal Psikologi Fakultas Psikologi Universitas Gajah Mada, 23 (2)

Burs, R., B. (1993). Konsep Diri: teori, pengukuran, perkembangan, dan perilaku. Jakarta: Arcan

Fatimah, E. (2006). Psikologi Perkembangan. Bandung: CV. Pustaka Setia

Geldard, Kathryn dan David Geldard. (2010). Konseling Remaja: Pendekatan Proaktif untuk Anak Muda. Yogyakarta: Pustaka Pelajar

Gita, Zulpahiyana, dan Siti. (2015). Faktor-faktor yang Mempengaruhi Konsep Diri Remaja, Jurnal Ners dan Kebidanan Indonesia, 3 (1)

Hidayat, Rahmat, D., \& Badrujaman, A. (2012). Penelitian Tindakan dalam Bimbingan Konseling. Jakarta. PT Indeks Hurlock, E., B. (1990). Psikologi Perkembangan. Jakarta: Erlangga 
Khalilah, E. (2017). Layanan Bimbingan dan Konseling Pribadi Sosial dalam Meningkatkan Keterampilan Hubungan Sosial Siswa. Journal of Islamic Guidance and Counseling. 1(1). 41-57

Maria, Ulfah and, Prof. Dr. Sartini Nuryoto (2007) Peran persepsi keharmonisan keluarga dan konsep diri terhadap kecenderungan kenakalan remaja. UNSPECIFIED thesis

Mudjiran, dkk. (2001). Perkembangan Peserta Didik. Padang: Dirjen Pendidikan Tinggi

Prayitno, E. (2006). Psikologi Perkembangan Remaja. FIP. UNP Padang

Prayitno. (2009). Dasar Teori dan Praksis Pendidikan. Padang: Grasindo (2014). Konseling Integritas : Pola Konseling Indonesia. Padang: Universitas Negeri Padang

Putri, M. O., \& Budi, A. (2003). Hubungan antara Dukungan Sosial Ayah dengan Penyesuaian Sosial pada Remaja Lakilaki. Jurnal Psikologi. (1). 23-35

Sarwono. 2011. Psikologi Remaja, Depok: PT. Rajagrafindo Persada

Soemanto, R. (2014). Pengertian dan Ruang Lingkup Sosiologi Keluarga, 1-45. (Online)

Yusuf, S. (2011). Psikologi Perkembangan Anak dan Remaja. Bandung: PT Remaja Rosdakarya 
